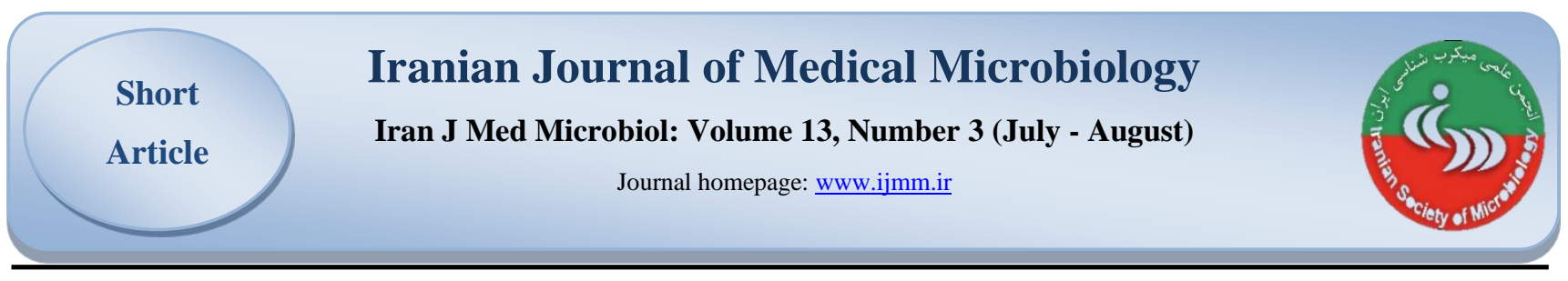

\title{
Evaluation of Antimicrobial and Antioxidant Activity of Essential Oil of Mentha piperita $\mathbf{L}$.
}

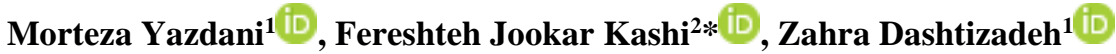

1. MSc, Department of Phytochemistry, Faculty of Chemistry, University of Kashan, Kashan, Iran

2. Associate Professor, Department of Cell and Molecular Biology, Faculty of Chemistry, University of Kashan, Kashan, Iran

\section{Article Information}

\section{Article Subject:}

Antimicrobial Agents

dei) $10.30699 / \mathrm{ijmm} .13 .3 .210$

Corresponding author:

Fereshteh Jookar Kashi,

Associate Professor, Department of Cell and Molecular Biology, Faculty of Chemistry, University of Kashan, Kashan, Iran

Email:

jookar@kashanu.ac.ir

Use your device to scan and read the article online

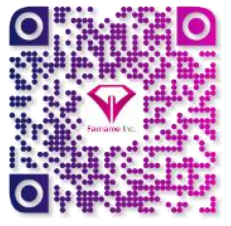

\section{Abstract}

Background and Aims: Increasing drug resistance to antibiotics in most bacteria has led to the development of natural antimicrobial compounds. Peppermint (Mentha piperita L.) is one of the most widely used herbs that has many therapeutic effects. The purpose of this study is the evaluation of antimicrobial and antioxidant activity of essential oil of Mentha piperita $\mathrm{L}$.

Materials and Methods: : In this study, after collecting and drying the leaves, essential oils of the plant was extracted using a solvent-free microwave extraction. The compounds of essential oil were identified by the GC-MS (Gas chromatography-mass spectrometry). The effect of antioxidant was determined by beta-carotene test and antimicrobial activity was carried using agar-dilution method also, the minimum inhibitory concentration (MIC) value was evaluated.

Results \& Discussion: Menthofuran, Menthol, and 1S-Neomenthyl acetate were the major compounds of essential oil of Mentha piperita L. collected from Marivan, respectively; menthol is the main compound of essential oil. The essential oil was more effective on gram-positive bacteria (Staphylococcus epidermidis, Bacillus subtilis, Staphylococcus aureus) and gram negative (Shigella dysenteriae, Klebsiella pneumonia) also had a good antioxidant activity compared to the standard BHT (butylated hydroxytoluene).Due to its relatively good antimicrobial and antioxidant properties, it can be used in the pharmaceutical and food industries.

Keywords: Antimicrobial activity, Antioxidant activity, Beta-Carotene, Essential oil, Mentha piperita L. , Menthol

Received: 2018/07/09 Accepted: 2019/08/14 Available online: 2019/08/14

Copyright ( $)$ 2019. This is an open-access article distributed under the terms of the Creative Commons Attribution- 4.0 International License which permits Share, copy and redistribution of the material in any medium or format or adapt, remix, transform, and build upon the material for any purpose, even commercially.

How to cite this article:

Yazdani M, Jookar kashi F, Dashti zadeh Z. Evaluation of Antimicrobial and Antioxidant Activity of Essential Oil of Mentha piperita L.. Iran J Med Microbiol. 2019; 13 (3):210-219

Download citation:

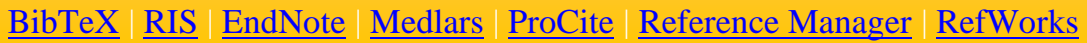

Send citation to:

Mendeley 2 Zotero $(\mathbb{H}$ RefWorks 


\section{Introduction}

Mentha piperita $\mathrm{L}$. with the common name "Peppermint" is one of the most important medicinal plants. This plant belongs to the family Lamiaceae, order lamiales. This plant is a natural hybrid of spearmint (M. spicata L.) and water mint ( $M$. aquatica L.) (1). It has the following general properties: antioxidant, antimicrobial, antiviral, antiseizure, anti-tumor, anti-allergic, anti-cancer, anticoagulant, analgesic and anti-insect (3). Its effective compounds include $1 \%$ volatile oil, resin, flavonoids, phenols, carotene, betaine and tannin (4). This study aimed to investigate the antimicrobial and antioxidant properties of $M$. piperita $\mathrm{L}$. and to determine its main constituents using gas chromatography mass spectroscopy (GC-MS).

\section{Materials and Methods}

The plant was collected from Marivan area (Kurdistan Province, Iran) during summer 2017 and approved by the Faculty of Botany at Kashan University. The essential oil was extracted by microwave method (Using the Microwave Reactor, Milestone MicroSYNTH Model) without solvent. The main constituents of the plant's essential oil were identified by gas chromatography/mass spectrometry (GC/MS) Agilent HP-6890 gas chromatography and Hewlett-Packard 6890-5972 (9). In this study, the antioxidant activity was investigated by $\beta$-carotene bleaching method (BHT standard as positive control) (10). The antioxidant activity was calculated using the "percent inhibition" formula:

$$
\mathrm{I} \%=\left(\mathrm{A}_{\text {sample }}-\mathrm{A}_{\text {control }}\right) /\left(\mathrm{A}_{\text {control}(0)}-\mathrm{A}_{\text {control }}\right) \times 100
$$

where $\mathrm{I} \%$ is the inhibition percentage, $\mathrm{A}_{\text {sample }}$ is the absorption of the sample, $A_{\text {control }}$ is the absorbance of the control and $\mathrm{A}_{\text {control( }(0)}$ is the absorbance of the control after the desired time. To investigate the antimicrobial activity, a set of microorganisms including Gram-positive and negative bacteria, fungi and yeast were used. The bacterial strains were cultured in Nutrient agar overnight at $37^{\circ} \mathrm{C}$ and fungi and yeast were cultured in Sabouraud Dextrose Agar overnight at $30^{\circ} \mathrm{C}$.

The antimicrobial activity was determined by agar diffusion method. The microbial suspensions adjusted to $0.5 \mathrm{McF}$ arland were cultured in Mueller Hinton Agar. At the end, the sample solutions were added to the wells. After $24 \mathrm{~h}$, the diameter of growth inhibition zones were measured.

To obtain the minimum inhibitory concentration (MIC), microdilution broth method was used according to CLSI (Clinical \& Laboratory Standards Institute) (11). The samples were first diluted with dimethyl sulfoxide (DMSO) in sterile tubes containing Brain Heart Infusion (BHI) broth. The sample solutions, 0.5 MacFarland suspension and BHI broth were added to each well. The samplefree well was used as negative control. After $24 \mathrm{~h}$, the lowest inhibitory concentration was considered as MIC. Rifampin and Gentamicin antibiotics (for bacteria) and Nystatin (for fungi) were used as positive controls.

\section{Results and Discussion}

The results obtained from analysis of the essential oil compounds using GC-MS are presented in Table 1. Menthol, neomentyl acetate and menthofuran were the main constituents of $M$. piperita L. essential oil, respectively and are highlighted in Table 1. In other studies, mentol, carvone, menton, neomentol and menthol acetate have been reported by Fadaie et al., (13). MimicaDukić et al., identified menthol (14) as the main constituents of $M$. piperita L. essential oil.

In other researches (reference), menthol has been found as a major component of the essential oil which is in accordance with our findings.

The lowest growth inhibitory concentration and diameter of growth inhibition zone of rifampin, gentamicin and nystatin antibiotics against the tested microorganisms are shown in Table 2 and those regarding the essential oil are shown in Table 3. The results showed that the essential oil has good inhibitory effect against Gram-positive bacteria. İşcan et al. and Sivropoulou et al. reported that peppermint essential oil had a greater effect against gram-positive bacteria than gram-negative bacteria $(21,22)$, which is similar to our findings. Tsai et al. reported the lowest inhibitory concentration of $0.08 \pm 0.00 \%(\mathrm{v} / \mathrm{v})$ for $C$. albicans and S. aureus (1). Afridi et al. reported the growth inhibition zone of $17 \pm 0.61 \mathrm{~mm}$ for $S$. aureus (23). 
Table 1. M. piperita L. essential oil constituents

\begin{tabular}{|c|c|c|c|c|}
\hline Number & Compound & Retention time (min) & Kovats index & Area \% \\
\hline 1 & alpha-Pinene & 6.34 & 939 & 0.67 \\
\hline 2 & Sabinene & 7.32 & 975 & 0.38 \\
\hline 3 & beta-Pinene & 7.43 & 979 & 0.97 \\
\hline 4 & 1,8-Cineole & 8.99 & 1031 & 5.84 \\
\hline 5 & trans-Sabinene hydrate & 10.09 & 1098 & 0.59 \\
\hline 6 & L-Menthone & 12.98 & 1152 & 3.49 \\
\hline 7 & Menthofuran & 13.34 & 1164 & 19.72 \\
\hline 8 & Menthol & 14.05 & 1171 & 41.21 \\
\hline 9 & Pulegone & 15.74 & 1237 & 1.23 \\
\hline 10 & Piperitone & 16.28 & 1252 & 0.28 \\
\hline 11 & 1R-Menthyl acetate & 16.71 & 1295 & 0.99 \\
\hline 12 & 1S-Neomenthyl acetate & 17.56 & 1273 & 21.49 \\
\hline 13 & Isomenthyl acetate & 17.87 & 1305 & 0.79 \\
\hline 14 & Isocaryophyllen & 20.93 & 1419 & 0.71 \\
\hline 15 & trans-Caryophyllene & 21.35 & 1419 & 0.82 \\
\hline 16 & Viridiflorol & 26.65 & 1592 & 0.52 \\
\hline 17 & Heneicosane & 39.25 & 2100 & 0.31 \\
\hline
\end{tabular}

Table 2. Antimicrobial effect of rifampin, gentamicin and nystatin antibiotics on Gram positive and negative bacteria

\begin{tabular}{|c|c|c|c|c|c|c|}
\hline \multirow{2}{*}{$\begin{array}{l}\text { Microorganisms } \\
\text { Gram-positive bacteria }\end{array}$} & \multicolumn{2}{|c|}{ Rifampin } & \multicolumn{2}{|c|}{ Gentamicin } & \multicolumn{2}{|c|}{ Nystatin } \\
\hline & $\mathrm{IZ}^{\mathrm{a}}(\mathrm{mm})$ & $\begin{array}{c}\mathrm{MIC}^{\mathrm{b}} \\
(\mu \mathrm{g} / \mathrm{mL})\end{array}$ & $\mathrm{IZ}(\mathrm{mm})$ & $\begin{array}{c}\mathrm{MIC} \\
(\mu \mathrm{g} / \mathrm{mL})\end{array}$ & $\mathrm{IZ}(\mathrm{mm})$ & $\begin{array}{c}\text { MIC } \\
(\mu \mathrm{g} / \mathrm{mL})\end{array}$ \\
\hline S. epidermidis & 40 & 250 & 35 & 500 & $*$ & $*$ \\
\hline B. subtilis & 13 & 15.6 & 21 & 500 & $*$ & $*$ \\
\hline S. aureus & 10 & 250 & 21 & 500 & $*$ & $*$ \\
\hline \multicolumn{7}{|l|}{ Gram-negative bacteria } \\
\hline S. dysenteriae & 8 & 250 & 18 & 500 & $*$ & $*$ \\
\hline K. pneumonia & 7 & 250 & 22 & 250 & $*$ & $*$ \\
\hline P. aeruginosa & - & - & 8 & 500 & $*$ & $*$ \\
\hline S. paratyphi-A serotype & - & - & 21 & 500 & $*$ & $*$ \\
\hline \multicolumn{7}{|l|}{ Fungi } \\
\hline A. niger & $*$ & $*$ & $*$ & $*$ & 27 & 31.25 \\
\hline A. brasilienis & $*$ & $*$ & $*$ & $*$ & 30 & 31.25 \\
\hline C. albicans & $*$ & $*$ & $*$ & $*$ & 33 & 125 \\
\hline
\end{tabular}

(-) antimicrobial inactivity.

(*) unusable antibiotic for the microbial strain.

a: inhibition zone.

b: minimum inhibitory concentration 
Table 3: Antimicrobial effect of Mentha piperita L. essential oil

\begin{tabular}{|c|cc|}
\hline Microorganisms & \multicolumn{2}{|c|}{ Essential oil } \\
\hline Gram-positive bacteria & $\mathrm{IZ}(\mathrm{mm})$ & MIC $(\boldsymbol{\mu g} / \mathbf{m L})$ \\
\hline S. epidermidis & 13 & $\mathbf{3 1 . 2 5}$ \\
\hline B. subtilis & 10 & $\mathbf{3 1 . 2 5}$ \\
\hline S. aureus & 10 & $\mathbf{6 2 . 5 0}$ \\
\hline Gram-negative bacteria & & $\mathbf{6 2 . 5 0}$ \\
\hline S. dysenteriae & 10 & $\mathbf{3 1 . 2 5}$ \\
\hline K. pneumonia & 11 & - \\
\hline P. aeruginosa & - & - \\
\hline S. paratyphi-A serotype & - & - \\
\hline Fungi & - & - \\
\hline A. niger & - & - \\
\hline A. brasilienis & - & \\
\hline C. albicans & & \\
\hline
\end{tabular}

(-) It means antimicrobial inactivity.

The results of the $\beta$-carotene bleaching assay showed that the inhibitory potency for inhibiting linoleic acid oxidation for BHT standard and the essential oil was $96 \%$ and $93 \%$, respectively. Accordingly, the percentage of inhibitory potency was very high, and this result indicated high antioxidant activity of $M$. piperita $\mathrm{L}$. The high antioxidant activity may be due to the presence of a major menthol in peppermint essential oil. Yadegarinia et al. (19) and Tabatabaei et al. (26) reported the inhibitory potency of the essential oil $50.17 \%$ and $41.3 \%$, respectively. Comparing the results of the present and other studies in Iran, it is found that the essential oil of $M$. piperita $\mathrm{L}$. extracted from Marivan county has a higher antioxidant activity compared to that from other locations investigated.

Different extents of antimicrobial and antioxidant properties as well as distinct essential oil constituents in different studies may be due to differences in geographical areas, climatic conditions, harvesting times, storage conditions and duration, method and duration of extraction, tested microbial strains and the environment of different crops, etc.

\section{Conclusion}

The results of this study showed that the essential oil of $M$. piperita L. cultivated in Marivan has good antioxidant and antimicrobial activity. The major component of the oil is menthol. The essential oil effects could be attributed to their monoterpene compounds. The essential oil of this plant is one of the natural sources of antioxidants which could be suggested to replace the synthetic source.

\section{Acknowledgments}

We are grateful to Natural Essences Research Institute of Kashan University for supporting this work.

\section{Conflict of Interest}

The authors reported no conflict of interest. 


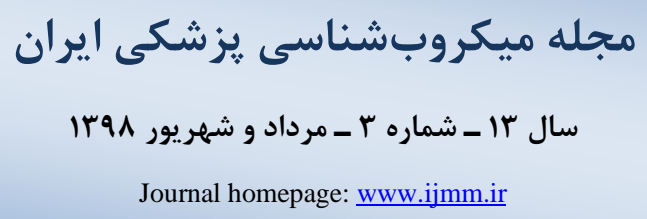

بررسى فعاليت ضدميكروبى و ضداكسيدانى اسانس كَياه نعناع نلفلى

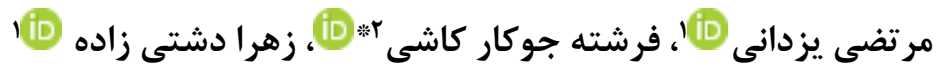

ا. . كارشناسى ارشد، فيتوشيمى، كروه فيتوشيمى، دانشكده شيمى، دانشعاه كاشان، كاشان، ايران

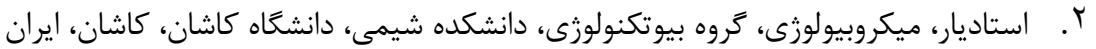

\section{جبكيده}

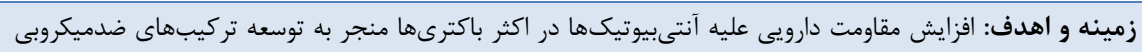

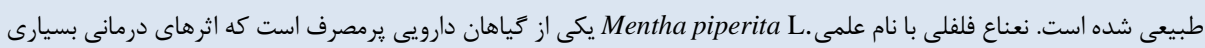

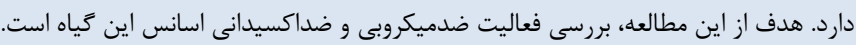

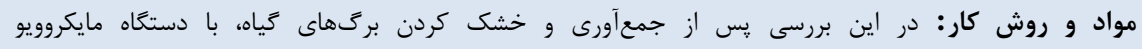

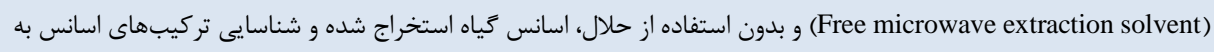

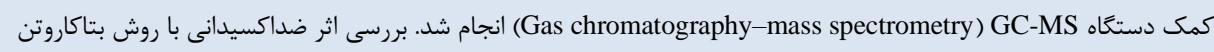

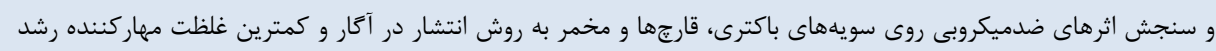
روى اسانس انجام شد.

يافتهها و بحث: منتول، نئومنتيل استات و منتوفوران بهترتيب عمدهترين تركيبهاى نمونهى اسانس نعناع فلفلى جمعآورى آنس

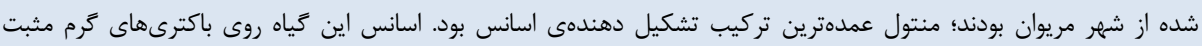

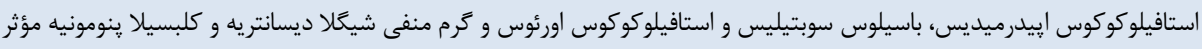

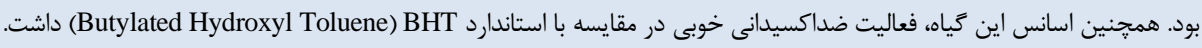

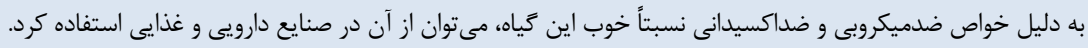
كليد وازهها: اسانس، بتاكاروتن، فعاليت ضدميكروبى، فعاليت ضداكسيدانى، منتول، نعناع فلفلى

كجى ايت ؟ مجله ميكروبشناسى بزشكى ايران: دسترسى آزاد: كيى بردارى، توزيع و نشر براى استفاده غيرتجارى با ذكر منبع آزاد است.

اطلاعات مقاله

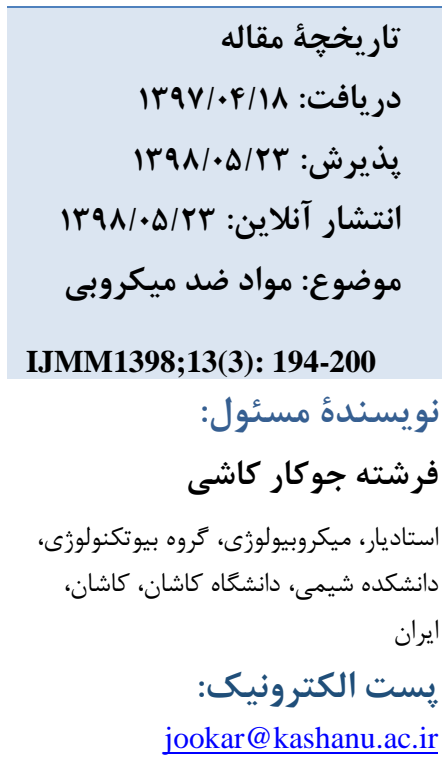

مقامها

تشكيلدهندهى اسانس آن منتول است كه از خانوادهى مونوترينهاى

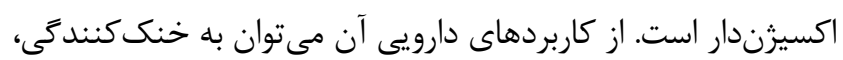

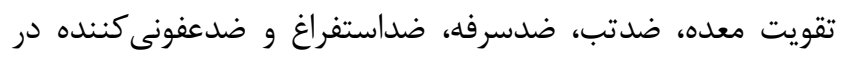

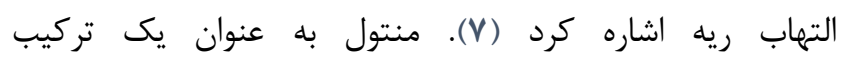

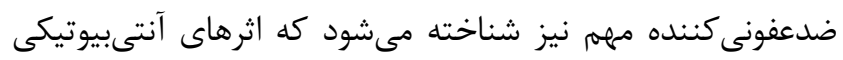

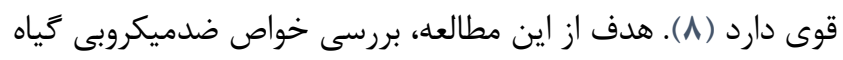

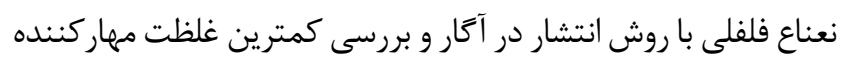

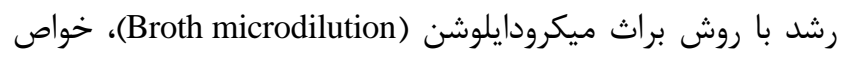

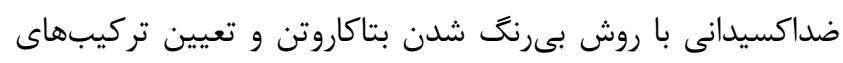

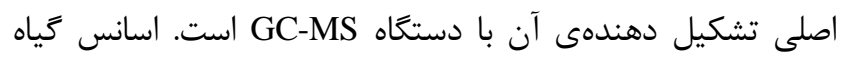
نعناع فلفلى در منطقه كردستان براى اولين بار است كه مطالعه إناه

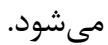

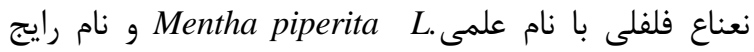

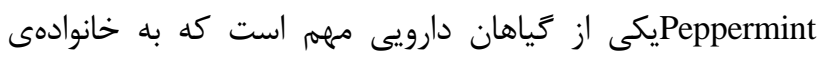
Lamialse Lamiaceae

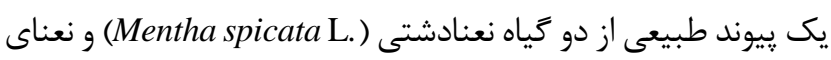

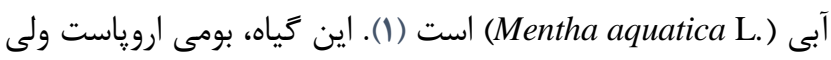

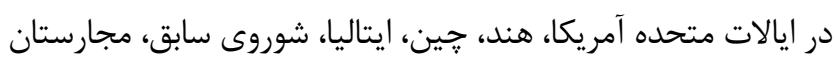

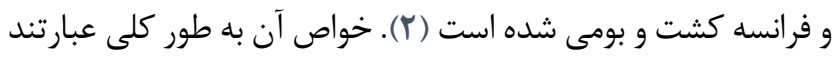

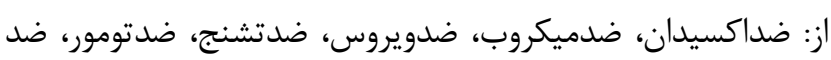

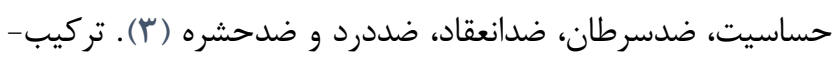

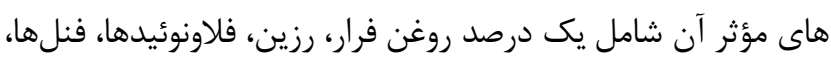

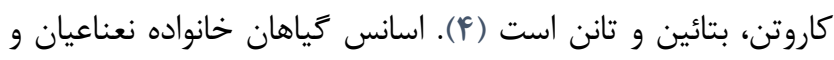

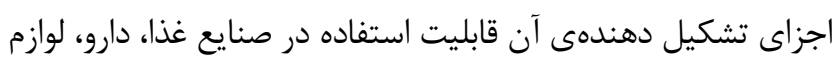

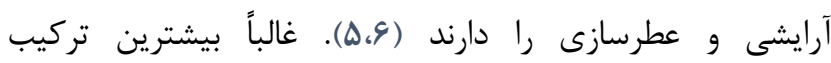




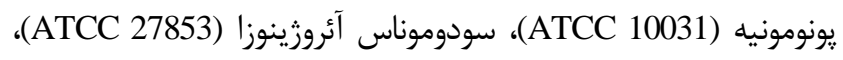

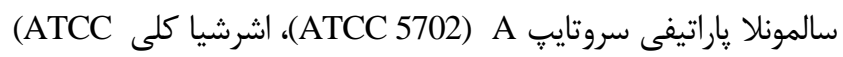

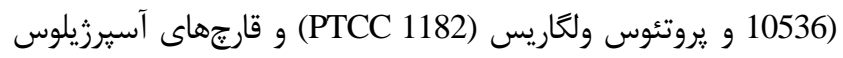

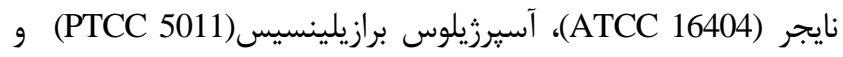

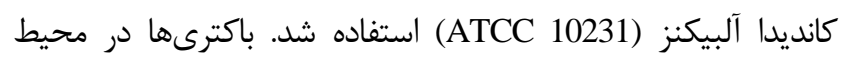
نوترينت آكار و قارجها و مخمر در محيط سابرو دكستروز آكار كشت داده

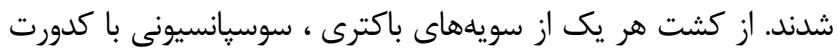

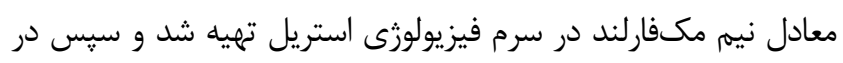

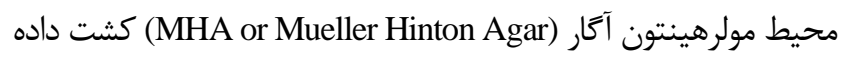
شدند. خاهكهايى در محيط ايجاد شد و سيس از محلول اسانس به هر

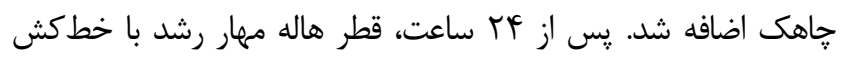

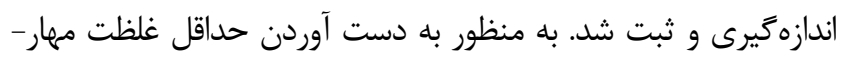
كننده براى سويههاى استاندارد حساس به اسانس از يليتهاى و 9 خانهاى استريل و روش براث ميكرودايلوشن طبق Clinical \&) CLSI (Laboratory Standards Institute هر ميكرواركانيسم به كدورت استاندارد نيم مكفارلند تهيه شد. نمونهها

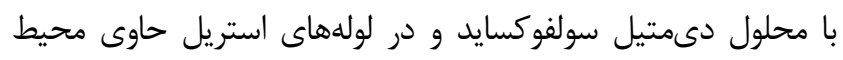
HHI(Brain Heart Infusion)

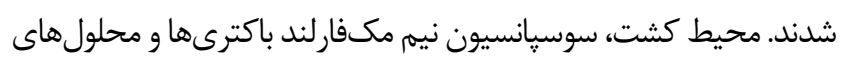

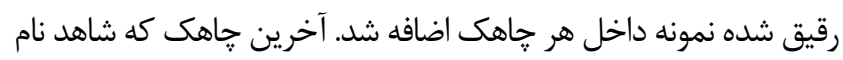

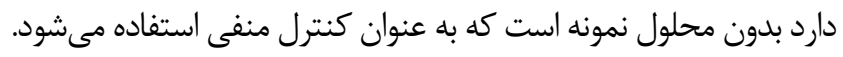

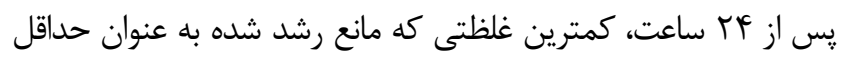

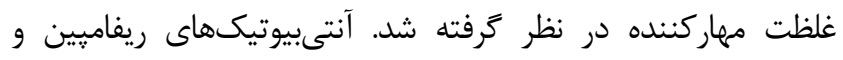

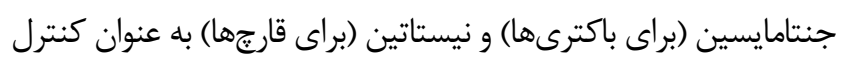
مثبت استفاده شدند.

\section{يافتهها و بحث}

دادههاى به دست آمده از آناليز تركيبهاى اسانس با استفاده از دستكاه GC-MS در جدول ا آمده است. منتول، نئومنتيل استات و منتوفوران بلترتيب عمدهترين تركيبهاى تشكيل دهندهى اسانس دانس

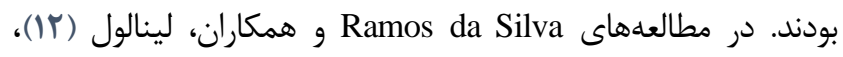
Fadaei

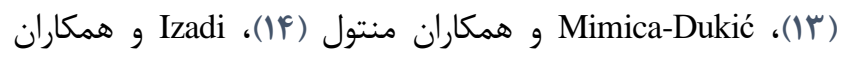

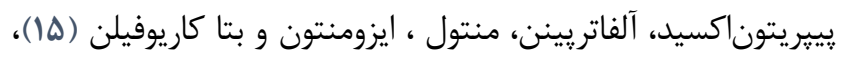
Tsai

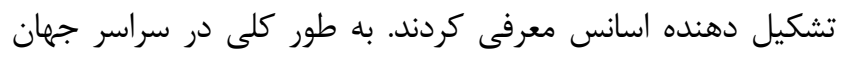

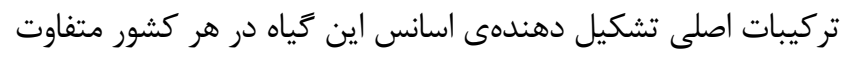
است. اين تركيبات در كشور صربستان منتون، منتول و منتيل استات

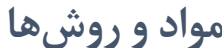

مطالعه حاضر از نوع تجربى است و يزوهشكده اسانسهاى طبيعى

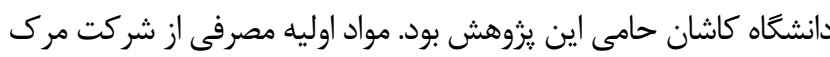

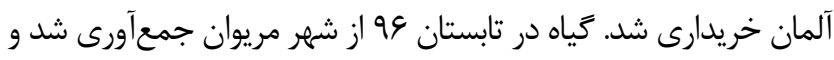

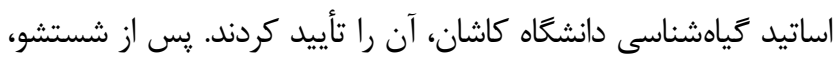

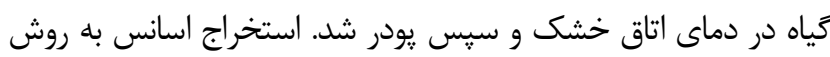

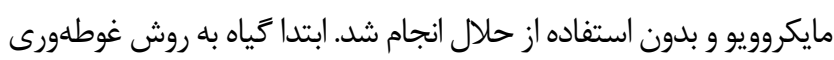

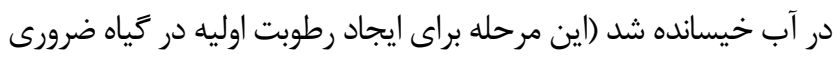

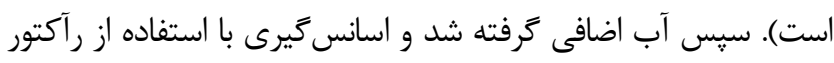

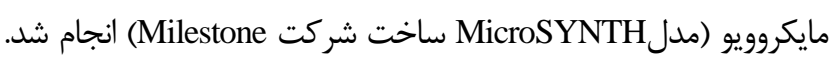

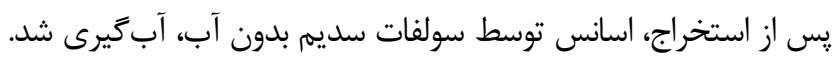

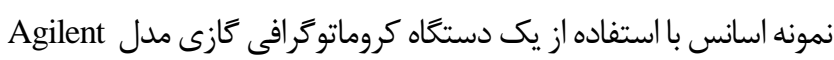

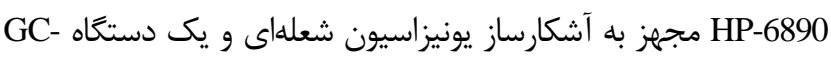

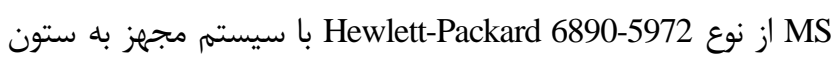
مويينه تجزيه شد. شناسايى اجزاى اسانس درنتيجلى مقايسهى طيف

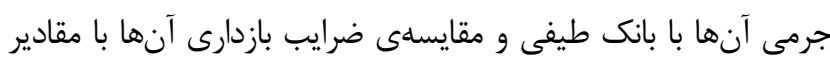

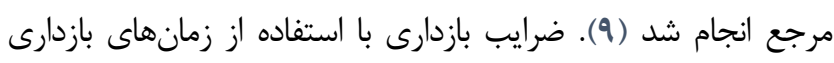

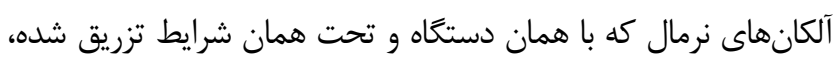

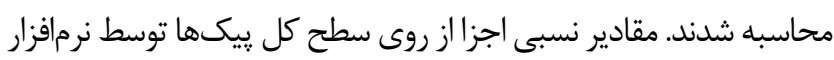

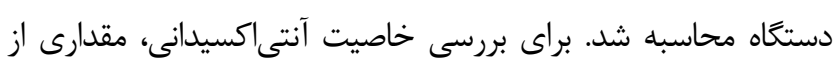

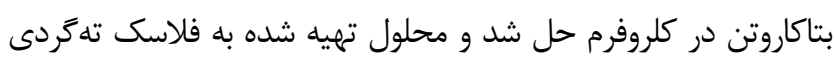

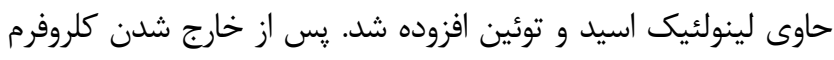

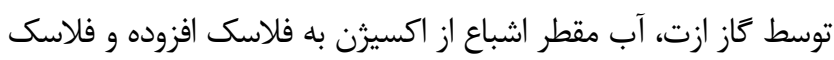

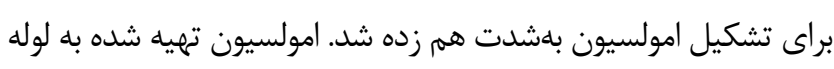

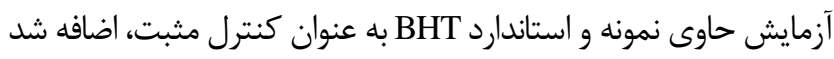

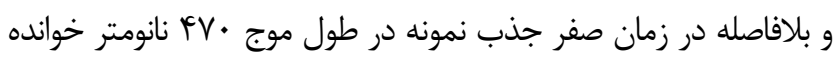

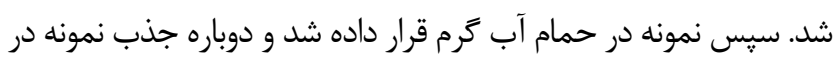

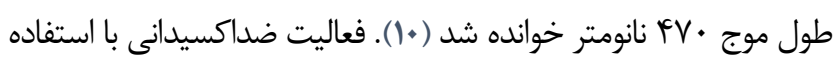
از فرمول "لارصد بازدارندگى" محاسبه شد:

$\mathrm{I} \%=\left(\mathrm{A}_{\text {sample }}-\mathrm{A}_{\text {control }}\right) /\left(\mathrm{A}_{\text {control( }(0)}-\mathrm{A}_{\text {control }}\right) \times 100$

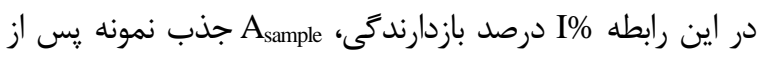

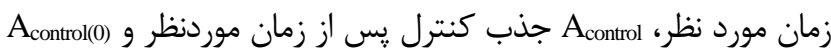

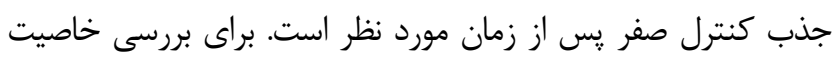

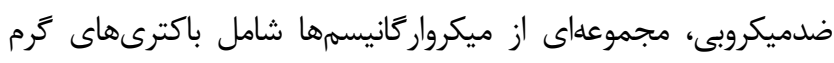
مثبت استافيلوكوكوس اورئوس (ATCC 29737) ، باسيلوس سوبتيليس

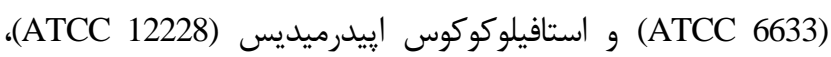
باكترىهاى كرم منفى شيخلا ديسانتريه (ATCC 1188) و (ATCC)، كلبسيلا 
اورگن (يكى از ايالتهاى غرب آمريكا) و هند به ترتيب منتول و منتون

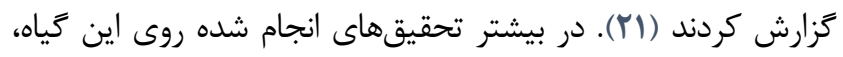
مشتقات از تركيبهاى اصلى تشكيل دهنده اسانس است كه با يافتهاى إنى ما همخوانى دارد و در جدول شماره ا هايلايت شده است.

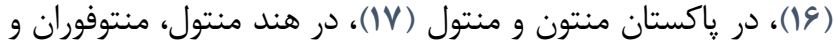

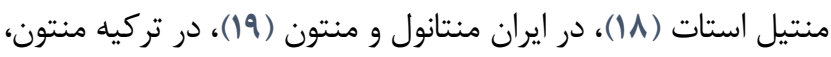
منتول، منتيل استات و منتوفوران (•r)، در برزيل لينالول (Y) (I) هستند. در مطالعهاى كه İş̧ و همكاران انجام دادند تركيبات اصلى تشكيل دهندهى اسانس رادر جهار منطقهى آداناى تركيه، ياكيماى واشينگتن،

جدول ا. تركيبهاى تشكيل دهنده اسانس

\begin{tabular}{|c|c|c|c|c|}
\hline شماره & 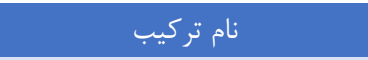 & زمان بازدارى & شاخص بازدارى & در ل مد \\
\hline 1 & alpha-Pinene & $9 / \pi F$ & 949 & $\cdot 19 \mathrm{~V}$ \\
\hline r & Sabinene & V/Tr & qva & $\cdot \pi$ \\
\hline r & beta-Pinene & V/FT & १จ१ &.$/ 9 V$ \\
\hline r & 1,8-Cineole & N/99 & $1 \cdot r 1$ & $\Delta / \Lambda F$ \\
\hline$\Delta$ & trans-Sabinene hydrate & 1.1 .9 & 1.91 & $\cdot 109$ \\
\hline 4 & L-Menthone & $1 \% / 91$ & $110 T$ & $r / 4 q$ \\
\hline v & Menthofuran & $I r / T F$ & 1194 & $19 / V T$ \\
\hline$\wedge$ & Menthol & $\mid \psi / \cdot \Delta$ & $11 \mathrm{VI}$ & $|F| / r \mid$ \\
\hline 9 & Pulegone & ID/VF & ITrV & $1 / r r$ \\
\hline 1. & Piperitone & $\mid g / T V$ & ITAT & $\cdot / r \Lambda$ \\
\hline 11 & 1R-Menthyl acetate & $19 / \mathrm{VI}$ & $1 \% 90$ &.$/ 99$ \\
\hline ir & 1S-Neomenthyl acetate & $I V / D S$ & IrVr & $r I / \& q$ \\
\hline ir & Isomenthyl acetate & IVIAV & $1 r \cdot \Delta$ & $\cdot / v 9$ \\
\hline 14 & Isocaryophyllen & $r \cdot / 9$ r & 1419 & $\cdot / N 1$ \\
\hline 10 & trans-Caryophyllene & TI/TS & 1419 & . AN \\
\hline 19 & Viridiflorol & relsa & 1095 & $\cdot \mid \Delta T$ \\
\hline IV & Heneicosane & rq/ra & rI.. & 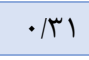 \\
\hline
\end{tabular}

S. aureus وماركننده را براى مخمر C. albicans

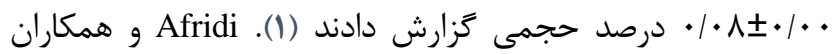
هالهى عدم رشد را براى باكترى S. aureus

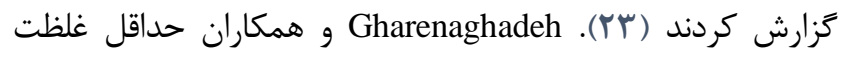

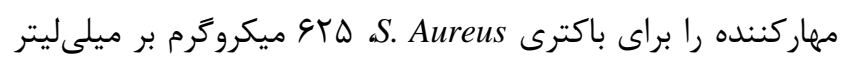

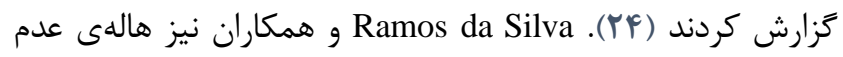

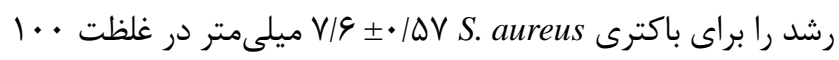

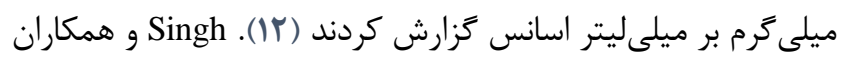

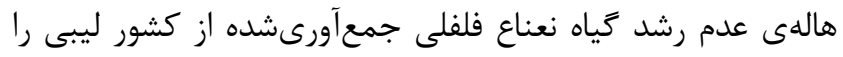

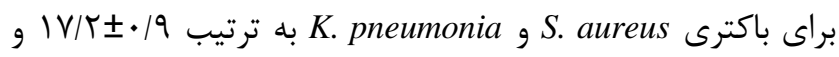

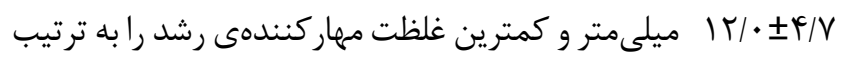

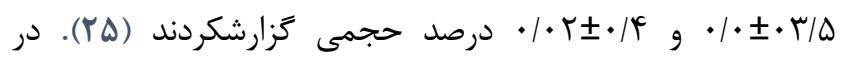
مطالعهاى كه İşscan و همكاران انجام دادند كمترين غلظت مهاركنندهى رشد اسانس جهار منطقهى آداناى تركيه، ياكيماى دادئ
كمترين غلظت مهاركننده رشد و قطر هاله عدم رشد

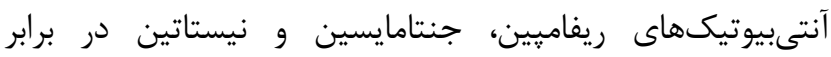

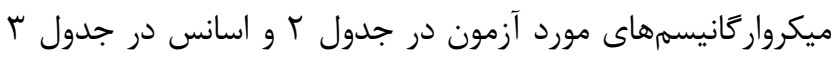

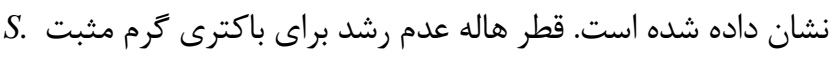
epidermidis C. albicans نداشت. براساس يافتههاى آزمون كمترين غلظت مهار كنينده رشد،

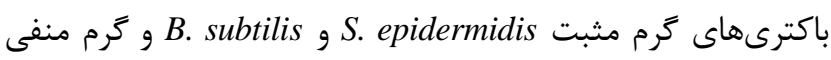
نسبت به سايرين اثر مهار كنندگى بيشترى داشتند.

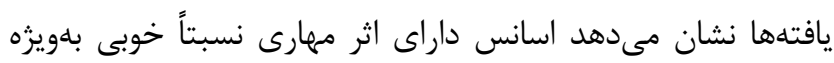

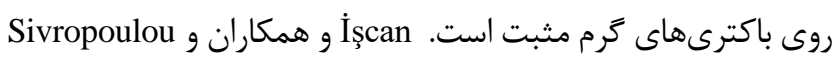

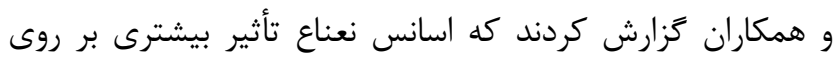

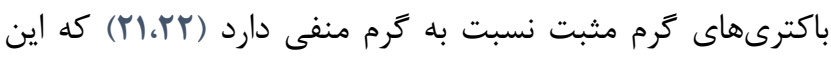

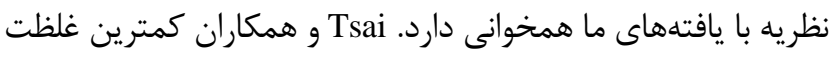




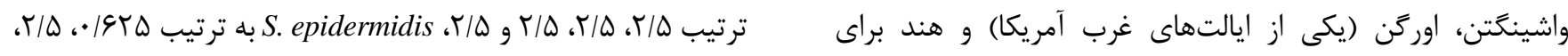

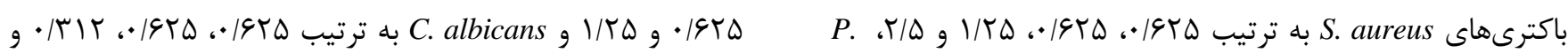
aeruginosa

$$
\text { جدول r. بررسى اثر ضدميكروبى آنتىبيوتيكهاى ريفاميين، جنتامايسين و نيستاتين }
$$

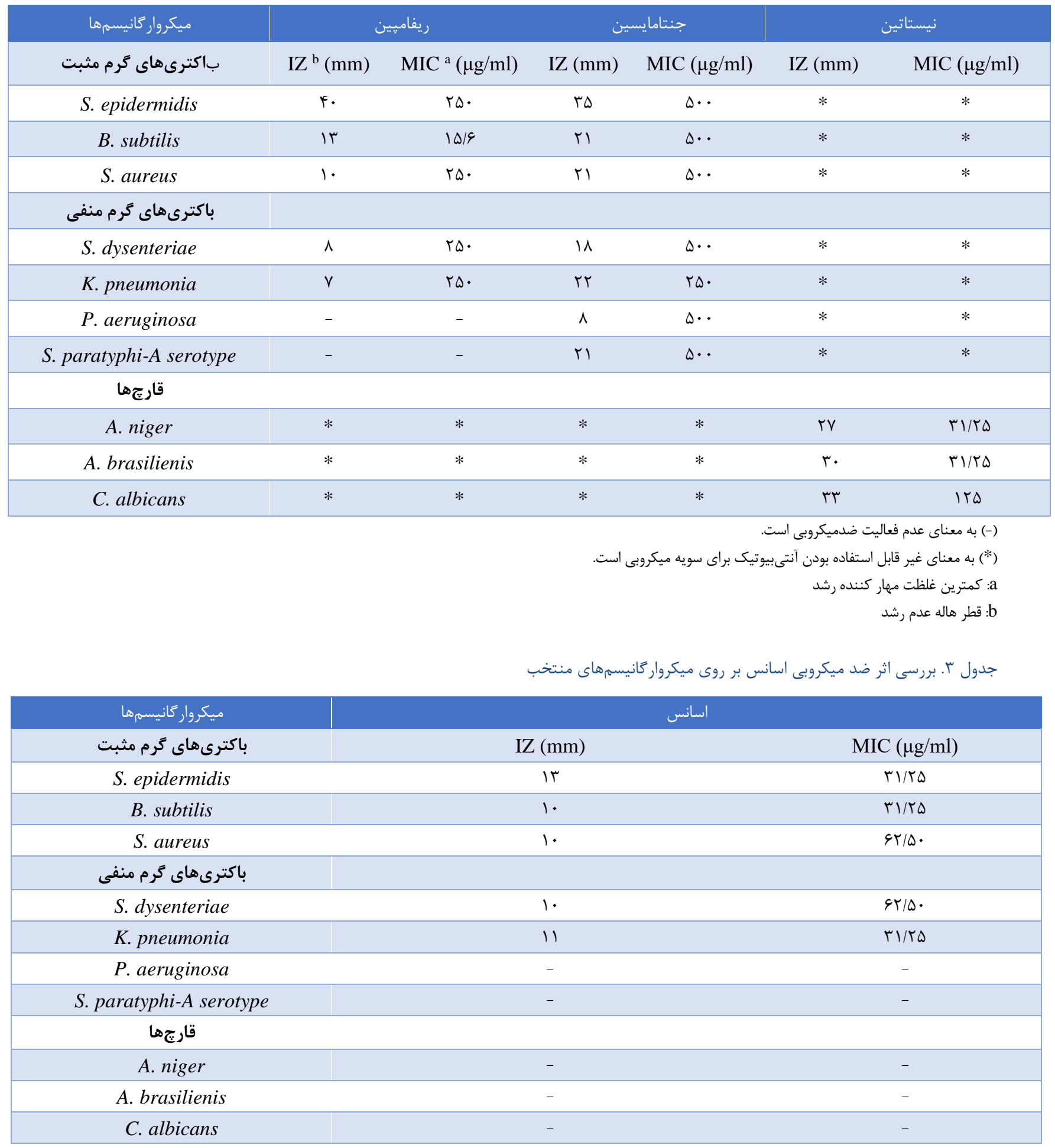




\section{نتيجه گَيرى}

يافتههاى حاصل از اين يزوهش نشان از قدرت مهاركنندگى و

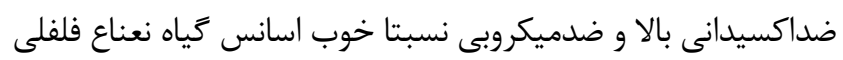

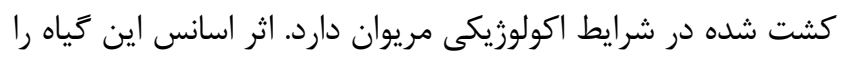
مىتوان به تركيبهاى مونوترينى و مقدار آنها در اسانس نسبت داد كه منتول شاخصترين آنها است. بنابراين اسانس اين گياه يكى از

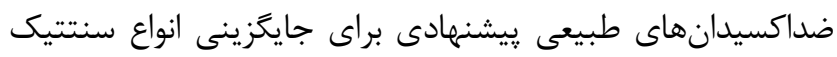
آن است كه مىتوان مطالعهها و تحقيقهاى بيشترى روى آن انجام

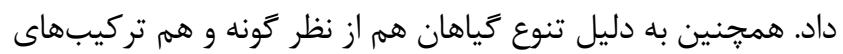

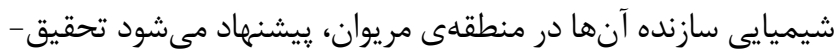
هاى بيشترى برروى زياهان اين منطقه صورت بخيرد.

\section{سياسگز ارى}

اين كار در يزوهشكده اسانسهاى طبيعى دانشعاه كاشان

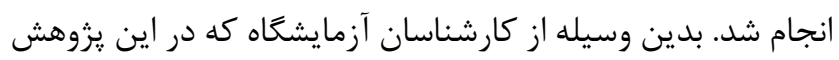
همكارى نمودهاند، تشكر و قدردانى مى كنيه.

$$
\text { بين نويسند تار تعارض منافع در منافع ززارش نشده است. }
$$

\section{References}

1. Tsai ML, Wu CT, Lin TF, Lin WC, Huang YC, Yang $\mathrm{CH}$. Chemical composition and biological properties of essential oils of two mint species. Trop J Pharm Res. 2013; $12(4): 577-82 . \quad$ [DOI:10.4314/ tjpr.v12i4.20]

2. Fatemi F, Dini S, Rezaei MB, Dadkhah A, Dabbagh $\mathrm{R}$, Naij S. The effect of $\gamma$-irradiation on the chemical composition and antioxidant activities of peppermint essential oil and extract. J Essent Oil Res. 2014; 26(2):97-104. [DOI:10.1080/10412905.2013. $\underline{871670]}$

3. Trevisan SCC, Menezes APP, Barbalho SM, Guiguer ÉL. Properties of mentha piperita: a brief review. World J Pharm Med Res. 2017; 3(1):309-13.

4. Hoffmann BG, Lunder LT. Flavonoids from Mentha piperita leaves. Planta Med. 1984; 50(4):361-369. [DOI:10.1055/s-2007-969736] [PMID]

5. Farnad N, Heidari R, Aslanipour B. Phenolic composition and comparison of antioxidant activity of alcoholic extracts of Peppermint (Mentha piperita). J Food Me:as char:act. 2010; 8(2):113-121. [DOI:10.1007/s11694-014-9171-x]
يافتههاى حاصل از اين آزمون نشان داد قدرت مهارى در

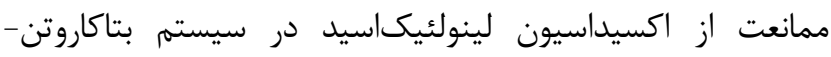

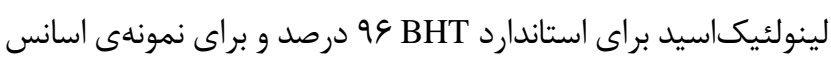
به درصد است كه براين اساس، درصد قدرت مهارى براى استاندارد

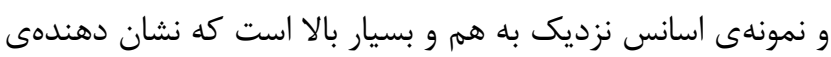

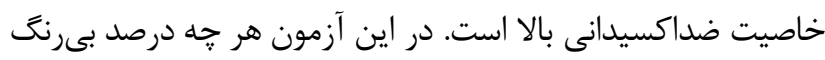

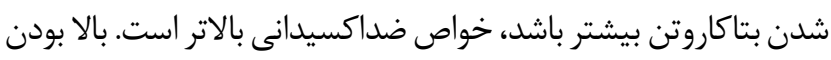

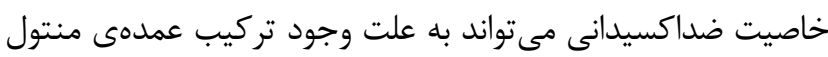
در اسانس نعناع فلفلى مطالعه حاضر باشد. در مطالعهى Yadegarinia

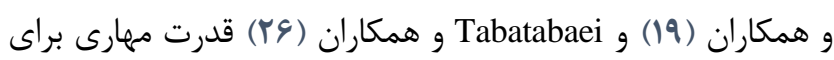

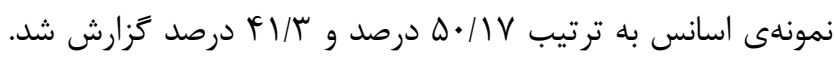

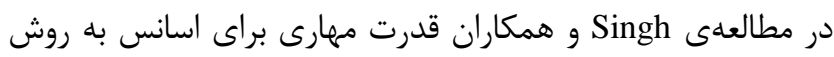

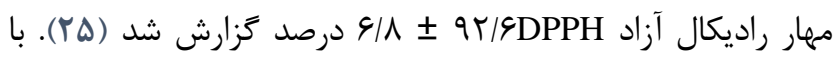
مقايسهى اين يافتهها با مطالعهى حاضر درمىيابيم قدرت مهارى و درنتيجه خاصيت ضداكسيدانى اسانس مورد مطالعه ما بيشتر است. متفاوت بودن خاصيت ضدميكروبى، ضداكسيدانى و تركيبات تشكيل دهنده اسانس در مطالعههاى مختلف ممكن است به علت تفاوت در

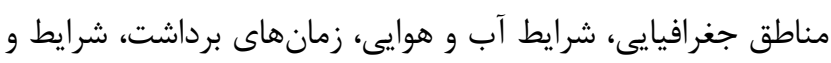

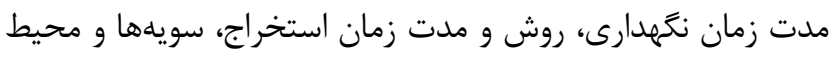

$$
\text { كشتهاى مختلف و ... باشد. }
$$

6. Rahmani F, Rezaeian-Doloei R, Alimoradi L. Evaluation of Phytochemical Composition of Mentha pulegium L. Essential Oil and Its Antibacterial Activity against Several Pathogenic Bacteria. Iran J Med Microbiol. 2018; 11 (6) :167-177

7. Clark GS. An aroma chemical profile. Menthol. Perfum Flavor. 1998; 23:33-46

8. Ernestt E, Pittler MH. The efficacy and safety peppermint (Mentha piperita L.): an update of a systemic review. Public Health Nutr. 2001; 3(4):50914.

9. Adams R. Identification of essential oil components by gas chromatography/mass spectroscopy. J Am Soc Mass Spectrom. 1997; 6:671-82. [DOI:10.1016/S1044-0305(97)00026-3]

10. Moure A, Franco D, Sineiro J, Domínguez H, Núñez MJ, Lema JM. Evaluation of extracts from Gevuina avellana hulls as antioxidants. J Agric Food Chem. 2000; 48(9):3890-7. [DOI:10.1021/jf000048w] [PMID]

11. Watts JL, Clinical and Laboratory Standards Institute. Performance standards for antimicrobial disk and dilution susceptibility tests for bacteria isolated from 


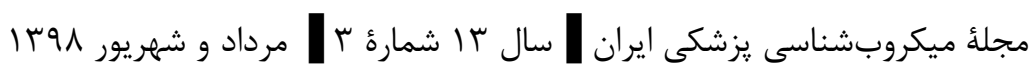

animals: approved standard. National Committee for Clinical Laboratory Standards; 2008.

12. da Silva Ramos R, Rodrigues ABL, Farias ALF, Simões RC, Pinheiro MT, Ferreira RMdA, et al. Chemical Composition and In Vitro Antioxidant, Cytotoxic, Antimicrobial, and Larvicidal Activities of the Essential Oil of Mentha piperita L.(Lamiaceae). Sci World J. 2017; 2017:1-8. [DOI:10.1155/2 017/4927214] [PMID] [PMCID]

13. Fadaei S, Aberoomand AP, Sharifan A, Larijani K. Comparison of Antibacterial Activity and Chemical Composition of Essential Oil Extracted from Mentha piperita L. Herb by Microwave and Hydrodistillation Methods. Food Technol Nutr. 2011; 8(3):28-36. (Persian)

14. Mimica-Dukić N, Božin B, Soković M, Mihajlović B, Matavulj M. Antimicrobial and antioxidant activities of three Mentha species essential oils. Planta med. 2003; 69(5):413-9. [DOI:10.1055/s-2003-39704] [PMID]

15. Izadi Z, Esna-Ashari M, Ahmadvand G, Davoodi P, Piri K. Chemical composition and antibacterial activity of the essence oil of peppermint (Mentha piperita L). Armaghane danesh. 2009; 14(3):45-54.

16. Soković MD, Vukojević J, Marin PD, Brkić DD, Vajs V, Van Griensven LJ. Chemical composition of essential oilsof thymus and mentha speciesand their antifungal activities. Molecules. 2009; 14(1):238-49. [DOI:10.3390/molecules14010238] [PMID] [PMCID]

17. Kanza S, Imran P, Hina B, Butt MS, Tayyaba I, Ushnah SU. Compositional profiling of Mentha piperita. Pakistan J Food Sci. 2014; 24(3):151-6.

18. Alankar S. A review on peppermint oil. Asian J Pharm Clin Res. 2009; 2(2):27-33.

19. Yadegarinia D, Gachkar L, Rezaei MB, Taghizadeh M, Astaneh SA, Rasooli I. Biochemical activities of Iranian Mentha piperita L. and Myrtus communis L. essential oils. Phytochemistry. 2006; 67(12):1249-55. [DOI:10.1016/j.phytochem.2006.04.025] [PMID]

20. Başer K, Kürkçüoğlu M, Demirci B, Özek $T$, Tarımcilar G. Essential oils of Mentha species from Marmara region of Turkey. J Essent Oil Res. 2012; 24(3):265-72. [DOI:10.1080/10412905.2012.676775]

21. İşcan $\mathrm{G}$, Kirimer N, Kürkcüoğlu Mn, Başer HC, DEMIrci F. Antimicrobial screening of Mentha piperita essential oils. J Agric Food Chem. 2002; 50(14):3943-6. [DOI:10.1021/jf011476k] [PMID]

22. Sivropoulou A, Papanikolaou E, Nikolaou C, Kokkini $\mathrm{S}$, Lanaras T, Arsenakis M. Antimicrobial and cytotoxic activities of Origanum essential oils. J agric Food Chem. 1996; 44(5):1202-5. [DOI:10.1021/i f950540t]
23. Afridi MS, Ali J, Abbas S, Rehman SU, Khan FA, Khan MA, et al. Essential oil composition of Mentha piperita L. and its antimicrobial effects against common human pathogenic bacterial and fungal strains. Pharmacol Online. 2016; 3:90-7.

24. Gharenaghadeh S, Forghani S, Gharehnaghadeh S, Sowti M. Evaluation of Antimicrobial Properties of Methanolic Extract, Essential Oil and Nanolipozom of Mentha piperita. J Food Sci Technol. 2017; 14(68):93-102. (Persian)

25. Singh R, Shushni MA, Belkheir A. Antibacterial and antioxidant activities of Mentha piperita L. Arab J Chem. 2015; 8(3):322-8. [DOI:10.1016/j.arabjc. $\underline{2011.01 .019]}$

26. Tabatabaei Yazdi F, Alizadeh Behbahani B, Vasiee AR, Mortazavi SA, Shahidi F. Evaluation antioxidant activity, phytochemical constituents and antimicrobial of Mentha Piperita essential oil on some infectious and poisonous microorganisms. J Food Sci Technol. 2018; 15(76):67-76. 